\title{
The Meaning of Visual Elements in the Mosque in Cirebon Sultanate XV Century Until the XXI Century
}

\author{
Nyai Kartika $^{1^{*}} \quad$ Amir Yasraf Piliang $^{2} \quad$ Imam Santosa $^{2} \quad$ Reiza D. Dienaputra ${ }^{3}$ \\ 1.Doctoral students of Art and Design \\ Faculty of Art and Design Institute of Technology Bandung \\ 2.Faculty of Art and Design Institute of Technology Bandung \\ 3.Faculty of Humanities, University of Padjadjaran
}

\begin{abstract}
Traditional buildings that are in Indonesia is so laden with meaning in every part of the elements. The meaning contains values that are affiliated in society. While the society itself is dynamic, always changing according to the development of the era. On the other hand the visual element that contains the meaning partly preserved, partly changed following the local socio-cultural circumstances because it is no longer relevant. In this case on an element of meaning can be interpreted as a reflection of the views and philosophy of life in society. Community which confirmed the existence of elements in traditional buildings, see it as a cultural property that is tied to the history of the lives of his ancestors. Similarly, the various visual elements contained in traditional mosques around the Sultanate of Cirebon. Therefore, this study will explore how deep the visual elements in traditional mosques around the Sultanate of Cirebon in the XV century to the XXI century with the title Meaning of Visual Elements in Mosques in the Sultanate of Cirebon in the XV century to the XXI century.This study uses Historical Methods. Historical method itself has four stages of work on the history of the heuristic method, criticism, interpretation, and historiography. In the heuriktik stages (collecting resources) do library research and field study. While the theory or concept used of which is the concept of culture and aesthetics. The results of this study shows the meaning of visual elements related exposure masjid around Cirebon Sultanate, namely Pejlagrahan Masjid, the Merah Panjunan Mosque, Tajug Agung Pangeran Kejaksanand Great Mosque of Cirebon.
\end{abstract}

Keywords: Elements, mosque, meaning, Cirebon

DOI: $10.7176 / \mathrm{HRL} / 50-02$

Publication date: November $30^{\text {th }} 2019$

\section{Preliminary}

Etymologically, mosque word comes from the Arabic mosque, which means place of prostration. From this mosque said later spawned a variety of derivative words in different areas Indonesia. In mesigit spoken Javanese, Sundanese Masigit, and in Madurese maseghit. In Jakarta mosque (between a and e) is spoken by people who are obedient, others mesigit (Pijper, 1984). Masigit in Sundanese such means as large mosque located in the city center, usually on the west plaza (Danadibrata, 2006).

The existence of words derived mosques in various regions does not diminish the words of the mosque itself. In fact, said the mosque until now a word more popular than other derivatives of words that are in the various regions. In its development until now, masjid often understood as the house where the Muslim Friday prayers or place of prayer daily, both to pray individually, or congregation. Mosques often also named person violated or surau. Violating or surau it normally also used to place the Koran, studying religion (Balai Pustaka, 1926).

Through the study of meaning Elements of Visual Masjid Wilayah Cirebon Sultanate, is expected to obtain a map of the visual culture of the format of the mosques in the Sultanate of Cirebon. In some areas of Indonesia still has a traditional kingdom and have power over their traditional territory tersebut.Model mosque be one measure of the presence on traditional royal palace tersebut.Mengungkapkan meaning of the visual elements of the mosque is considered important because it shows that not all public representatives of the public know about it. Knowledge of the meaning of the visual elements of the mosque is only known by a small fraction segments of society that are in Cirebon. With this research, is expected to enrich the local historiography in Cirebon in particular and the writing of history in general.

As for metode used in penelitian this is the historical method. Historical method is the process of testing and critically analyze the records and relics of the past. This method consists of several stages: heuristic, criticism, interpretation, and historiography (Gottschalk, 1986: 32).

\section{Discussion}

Before starting the discussion about the meaning of the visual elements of mosques around the Sultanate of Cirebon, Cirebon of historical discussion will be presented as backgroundback to read the contexts of meaning visual elements mosque into the discussion. Ekadjati $(1991,126)$ revealed that before, led by Sunan Gunung Jati and into the kingdom of Islam, Cirebon is divided into two areas, namely the so-called coastal areas and hinterland Disallow Cirebon Girang called. Areas along the coast of Cirebon (Cirebon bans) controlled by Ki Gedeng Jumanjati as 
Singapore local authorities, and the port of Muara Jati. Region of Cirebon Girang around the foot of Mount Ciremai controlled by Ki Gedeng Kasmaya which is Wanagiri regional authorities. Both rulers is the brother of King Anggalarang (Tohaan) Galuh.

During the reign of Sunan Gunung Jati, Cirebon able to break away from the Kingdom of Sunda Pajajaran who at that time headed by Sri Baduga power Maharaja. This period is known as the kingdom of the independent and sovereign with an area covering Luragung, Brass, Banten, Sunda Kalapa, Galuh, Soil, Sand Luhur, Sejong, Japura, etc. As stated in (RI Department of Education, 1998: 11-12) that the boundaries of most of West Java is now named were then divided into two in the period Panembahan Queen (grandson of Sunan Gunung Jati who replaces his leadership) into west Citarum is Banten and east of the Citarum including Cirebon.

When Daendels became Governor General in 1808 the territory has not changed. Daendels then split into three parts of Java Island and enter the Sultanate of Cirebon and Cheribonsche Preanger Regentschappen (Limbangan, Sukapura, and Galuh) into a separate section. Meanwhile on February 2, 1809 the Dutch government issued a special regulation governing the division of power and authority in Cirebon in Beheer van het Reglement of Landen mentioning Cheribonsche Cirebon Sultanate territory covers an area of Cirebon, Kuningan, Indramayu, and Gebang. Until the enactment of the 1903 Wet Decentralitatie Cirebon seroreverting government. Beginning with the division of the empire into three on March 13, 1809, into a future residency Cirebon Raffles, Cirebon inauguration on May 24, 1862 (LG DT 1 Jabar, 1993: 261). The formation of the municipality (gemeente) (Staadblad 1906/122) to the administrative territorial division Provincie West Java in 1922 which among other things regulates the residency Cirebon Cirebon capital consists of four districts namely; Cirebon, Indramayu, Majalengka and Kuningan (Ciayumajakuning) (Regeringsalmanak voor Nederlandshe-Indie, 1923: 133-134, 197205 and 1925: 215-223).

Until the 20th century the Cirebon change the form of government that constantly. It is also ultimately affect the area or territory that includes Cirebon, be it as a sovereign kingdom, as residency, county, or city. Cirebon topography consists of coastal areas, plains and plateaus or mountains. Are generally tropical climate with temperatures from June to October to reach $32,5^{\circ} \mathrm{C}$ temperature. located between $108^{\circ} \mathrm{BT}$ and $9^{\circ} \mathrm{LS}$ with a height of land between 0-130 meters above sea level. Rainfall is on average $1,963 \mathrm{~mm} /$ year with humidity peaked in May, reaching 945 with the highest rainfall in the central and southern parts, which is a hilly area at the foot of the mountain Ciremai (Dahuri, et al., 2004: 13).

The coastal area of Cirebon is located in Cirebon the north and east with the climate tends to be hot as a result of natural conditions which mostly consists of pantai.Dengan area coastline length is about $170 \mathrm{~km}$, this region is the largest producer of fish are plentiful and their processed products. While the lowlands and the highlands of Cirebon with rice area reached 9,180 hectares and extensive moor reached 2,550 hectares is landscape agricultural areas and large plantations and lush with the main results of rice, sugar cane, vegetables, coffee and timber with good quality and plentiful (Raffles, 2014: 105).

Dith the presence of beaches and vast plains, supported by abundant water resources, the number of large and small rivers that reached 200 as well as a good irrigation system, our region and opportunities allow residents to choose livelihood based on the natural conditions. Coastal communities with livelihood predominantly fishermen, and the population of lowland and upland farms and plantations, in addition to trade both small scale and large scale.

Especially for coastal areas Cirebon, some history shows the activities of shipping and trade since the 14th century and 15th in the kingdoms of the coast such as Majapahit, Malacca, Aceh, Demak, Tuban, Banten, Bali, East Kutai, Kalimantan Selatan, Makasar, Maluku, including Cirebon and others. These places have become a center of trade in the archipelago as well as international trade which includes Vietnam, Cambodia, Burma, China, India, Arabia, Syria, East Africa to Europe (Wardaya, 2001: 23). In other words, the geographical position Cirebon located on the north coast of Java as well as a path that connects several major cities in Java allow trade transactions, both inter-island and inter-state (international trade).

Additional support was obtained from the presence of the port forward to include one of the four most advanced port in the island of Java in addition to the port of Jakarta, Surabaya and Semarang. Cirebon position located on the island of Java and is directly adjacent to the north coast of Java sea, with a long coastline, coupled with bay Muara Jati establish this area as well as port and shipping trade lanes are located. A geographical analysis expressed by JJ Baggelaar (TT, 130-131), Singgih Tri Sulistiyono (1994, 39-40), and Veth 1982: 195 states that the port of Cirebon has a very strategic location because it is on a bay that is protected by a peninsula Indramayu and corals in the offshore portion of the brunt of the waves coming from the Java sea north.

In the context of the history of Cirebon, three geographical factors, namely the coastal, highland and lowland becomes imperative for the permanence of the colonial government power. Starting from the fulfillment logistical reasons and in order to increase profits colonial government as well as efforts to find a solution to the financial problems faced, since VOC until the Japanese occupation of Cirebon, coastal lowlands and the highlands of Cirebon not escape from the treatment of the colonial government. This means things should be noted first is geographical position Cirebon strategic role. The coastal area is not only simplify and economically profitable, but 
also open up competition more competitive. Starting with the trade by sea and along with agricultural activity,

Entering the discussion about the historical significance of the visual elements in the Sultanate of Cirebon mosque, the mosque is the subject of this study is limited. Because of the many indicators of the mosque by periodeisasi, location, and style. Thus, restrictions Common Object: Four mosques in the Sultanate of Cirebon that Pejlagrahan Masjid, the Merah Panjunan Mosque, Tajug Supreme Prince Kejaksan, and the Great Mosque of Cirebon. Fourth mosque is located in the city of Cirebon, and was founded in the XV century AD The discussion was divided into a number of elements that the authors believe to be meaningful (historical and social) visual elements.

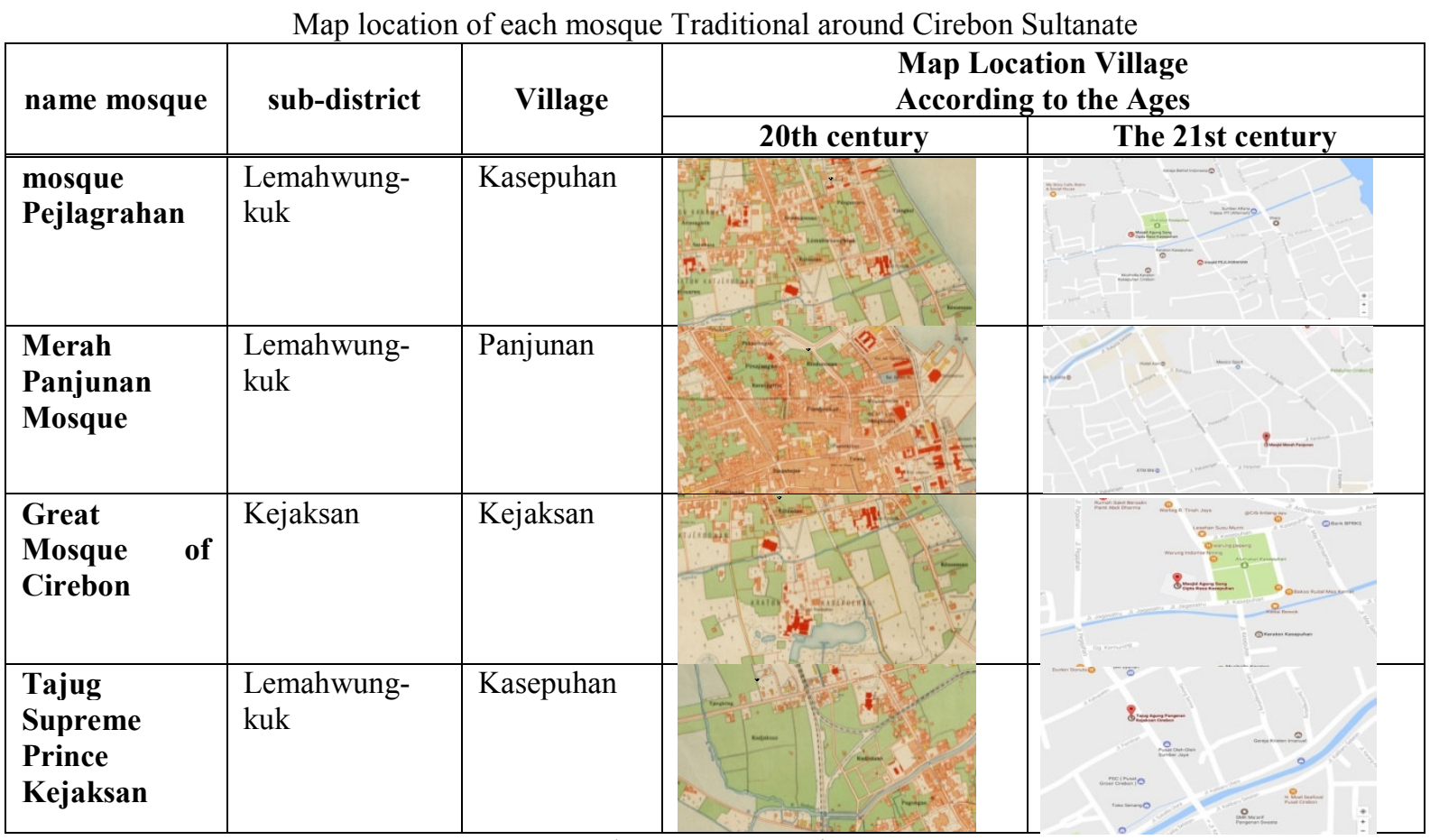

Source: .google maps accessed June 2, 2017

The first element is the gate. Symbolization other meanings more fully in the mosque that contains the values that can be seen from the combination of the structure. The gate symbolizes the temple where the building of the temple there are three levels prior to the summit. As well as sequences entered the mosque, before arriving at the sanctuary, a Muslim must pass the three parts of the mosque is a puddle of water (pond) to purify themselves later foyer, main hall and a new mihrab or the imam. This is similar to the one put forward by (Hashim, 2011) that the arch-shaped recesses diagonal half-circle is a symbol the Arab or Muslim world.

At the Merah Panjunan Mosque, Tajug Supreme Prince Kejaksan, and the Great Mosque Sang Cipta Rasadipertahankan.Gapura where the gate was originally made from clay and bricks are arranged. At present the gate in the Great Prince Tajug existing Kejaksan addition of an iron fence. It is possible to maintain the security of the mosque. The existence of the gate shows the development of the mosque in Cirebon get a strong Hindu influence. This is quite reasonable since before the $15^{\text {th }}$ century Cirebon Sultanate territory was still under the influence of Hinduism and Buddhism. Fourth mosque, which studies this research that established Pejlagrahan Mosque 1445/1452 Panjunan M. Red Mosque was founded in 1480 AD Tajug Agung Pangeran Kejaksanestablished in 1479/1480 M. 


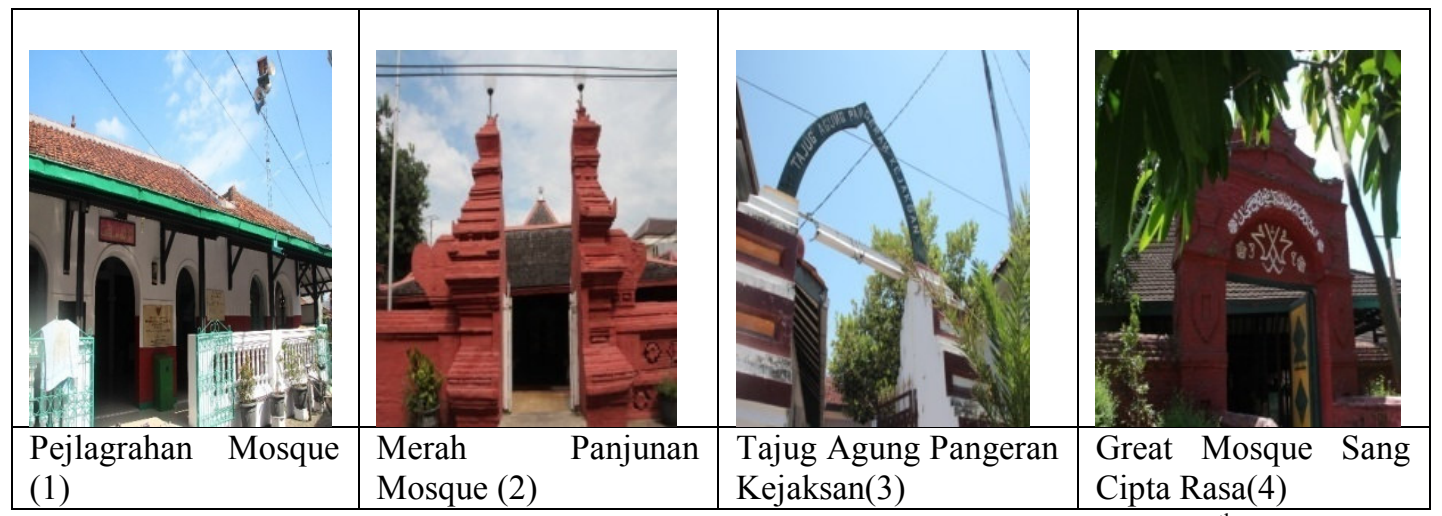

Figure 1, 2, 3, 4: Photos of the fourth gate of the mosque (July $26^{\text {th }} 2016$ )

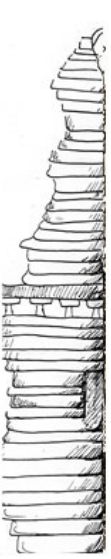

Gapura

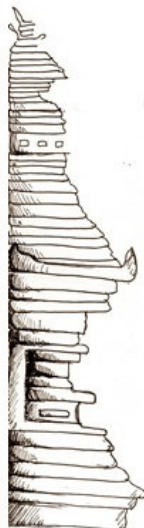

Illustration Gate (Nevita, 2018)
Gapura Tajug Agung Pangeran Kejaksan

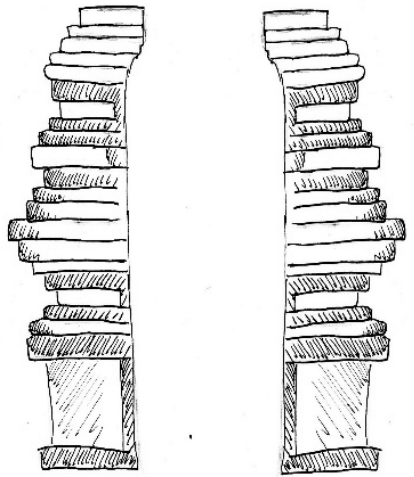

It can be seen from the variety of ornaments mosque located in the Sultanate of Cirebon. This is confirmed by the presence of Cirebon which is a regional port since the 17th century, based on the report Tome Pires. Because of its function as a port that allows interaction with a high intensivity, as well as an entry point for traders from various ethnic group to go to Cirebon. By doing so, allows multiculturalism in Cirebon occur. The meeting between cultures of various ethnic groups can not be avoided anymore. In connection with the mosque ornaments that contain properties can terilhat multiculturalism in the gate.

The next element is maksurah. In addition to the gate, there maksurah, and the mihrab attract attention when entering the mosque. After going through the gate, into the courtyard of the mosque, then on the porch, and finally enter the main prayer hall. Will encounter unique in the Great Mosque Sang Cipta Rasathat their maksurah. There is some sense of which is maksurah maksurah a small building located on the left of the mihrab and serves as a place of worship the king or ruler, maksurah made of teak wood of a certain size (Maryanto, 2009).

Maksurah is a special room reserved for the King or Sultan's prayer. Maksurah usually found on ancient mosques associated with the kingdom (Ramelan, 1997). Maksurah is a small building which is located on the left pengimanan / mihrab in the front rows (Haryadi, 2002). Maksurah is the designation of a place berbetuk a rectangle on the front inside a mosque, often made of iron which is beautiful and strong, used to place the king, or people who need to be protected from interference that may occur during the worship (Effendy, 2001). Maksurah is a place that is only found in the sultanate mosque that serves as protection for the sultan and high officials of the kingdom during prayers in the mosque of the possibility of physical attacks against royal officials.

Visually it looks there is a hierarchy in the Great Mosque of Cirebon. This can happen in a mosque that the mosque is a place that supposedly egalitarian, with no tendency and discriminating status and position. Meanwhile, around the mosque in Cirebon Sultanate, maksurah itself only in the Great Mosque of Cirebon. The old mosque in the territory of the other Cirebon Sultanate no maksurah. This has become one of the uniqueness of the Great Mosque of the Taste. 


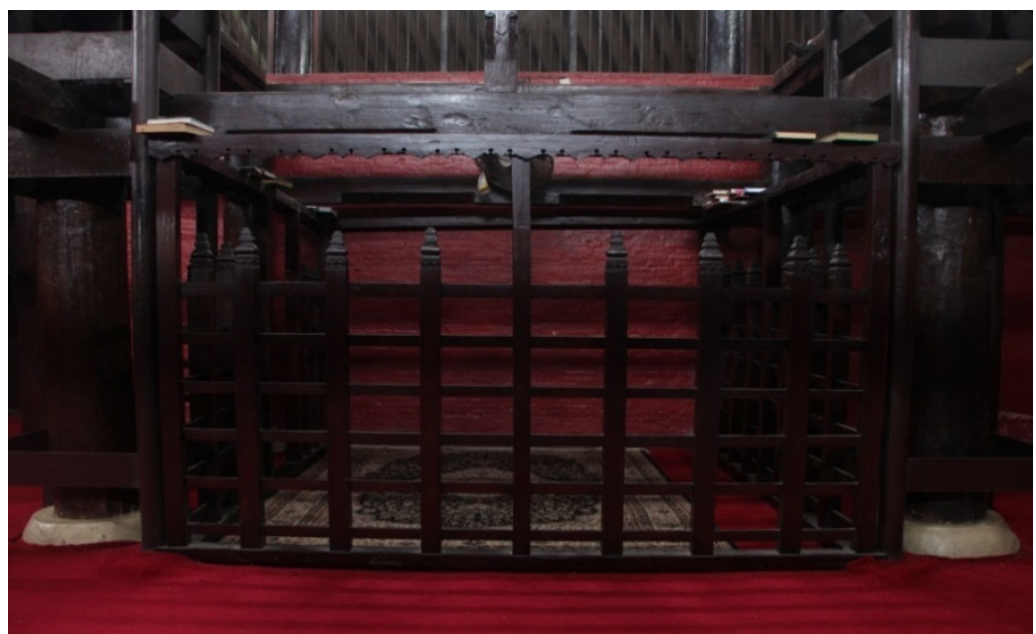

Image: Maksurah in the Great Mosque Sang Cipta Rasa (July $\left.26^{\text {th }} 2016\right)$

According to TD Sudjana (2003) and PS Sulendraningrat (1956) that the presence of maksurah estimated to have existed since 1786 AD was made on the initiative Sepuh Sultan Hasanuddin Mohammed VI. Sepuh Sultan Hasanuddin original name is Ki Young. He is pawongan (aide) Mohammed Sultan Sepuh Shofiudin Matangaji. Sultan Mohammed V Sepuh Shofiudin Cirebon Matangaji is the first against the Dutch. Holland always loses in the fight against the forces of Sultan Matangaji. Finally, the Netherlands seeking a mediator to negotiate with the Sultan. Ki Young was willing to be a mediator with the condition, and the Netherlands agreed. When Sultan Matangaji willing to negotiate, Netherlands betrayed the Sultan Matangaji arrested later killed by Ki Young. Finally Ki Young asked for the terms promised. Dutch fulfill that requirement by raising Ki Young became Sepuh Sultan Mohammed VI with the title Sultan Hasanuddin. Sultan Hasanuddin always overshadowed by the fear of his life, so for Friday prayers at the Great Mosque of Cirebon, he should be heavily guarded. Then built maksurah or Krapyak.

Until now maksurah remain in the mosque, which is a fortress of defense if the sultan doing daily prayer. Though conditions after independence, and the conflict is not apparent, such as the colonial period. This can be attributed to their exclusion Cirebon society; especially with regard to socio-political systems prevailing in Cirebon. Moreover, the existence of which is retained maksurah shows a representation of the people's resistance against the flow changes Cirebon.

Next is the Mihrab, considered the holiest part among the parts of the mosque, such as prominent buildings standing on the hall of the mosque. The roof is in the form of an arch, the dome-like cylinder and a convex dome. Mihrab is the room where the prayer that is usually semicircular or shaped like a horseshoe and also serves as a hint towards the Qibla of Muslims in worship that is toward the Kaaba. In the past, before the mihrab Muslims difficult to determine the direction of Qibla, Abu Bakr explained that if the Grand Mosque in Mecca easily Muslims determine the direction of Qibla, as the mecca of prayer located in front of the eye. However, it is difficult for other than the Haram mosque to determine the direction of Qibla. Therefore, it is marked by a kind of sign Qibla arch called "mihrab" which is usually used as a stand priest at the time to lead the prayer, it is on the left of the pulpit on which to preach (Bawono, 2000). Understanding others explained that the mihrab is the Qibla direction sign at a mosque located on the central axis of the mosque or also called haram (Sumalyo, 2006). Mihrab in the mosque Pejlagrahan seen already undergoing renovations so there is no visible carving on the wall just mihrab mihrab has been replaced with ceramic mihrab of the mosque is very small and only enough for a priest alone. At Merah Panjunan Mosquemihrab there are some decorations or ornaments resembling lotus flowers were 8 pieces with the tip of the left and right side of the mihrab vine motif. Tajug Agung Pangeran Kejaksan the top of the mihrab incised carving the image of the Chinese model. It shows in addition to being a strong Hindu influence the development of mosques in Indonesia can not be separated from the development of Islamic sculpture at the outset centered on mosques and palaces.

On the mihrab Great Mosque Sang Cipta Rasathere is an engraving stuck exactly where the establishment of a priest and shaped carving of a lotus according to oral tradition that developed in Cirebon, that the lotus flower was created by Sunan Kalijaga. Based on information from the Kasepuhan palace symbolizes the symbol of philosophy Hayyun Ila Ruhin (living without a soul). In front Pengimaman also there are three tiles were specially marked, because it has traditionally value. The third tiles installed at the time of establishment of the mosque by Sunan Gunung Jati, Sunan Bonang and Sunan Kalijaga. Third tiles were installed by the third character is supposed guardians of society also means the symbol teachings. Namely Islam Iman, Islam and Ihsan. 


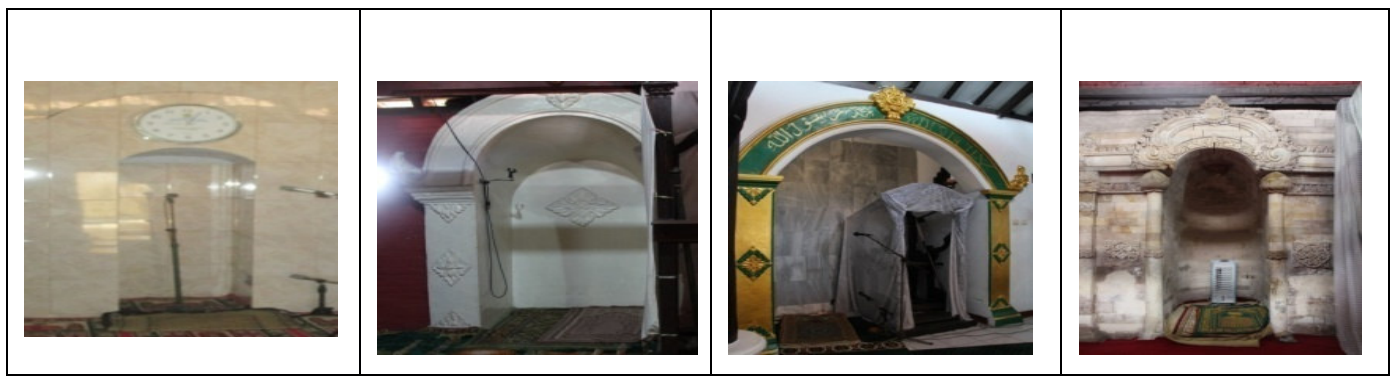

Image: Fourth mosque MihrabSource: Documentation of the author (July 26th 2016)

Therefore, the shape of the fourth mihrab of this mosque shows also the complexity of multiculturalism in Cirebon embodied in the mosque ornament. It can be seen from the variety of ornaments mosque located in the Sultanate of Cirebon.

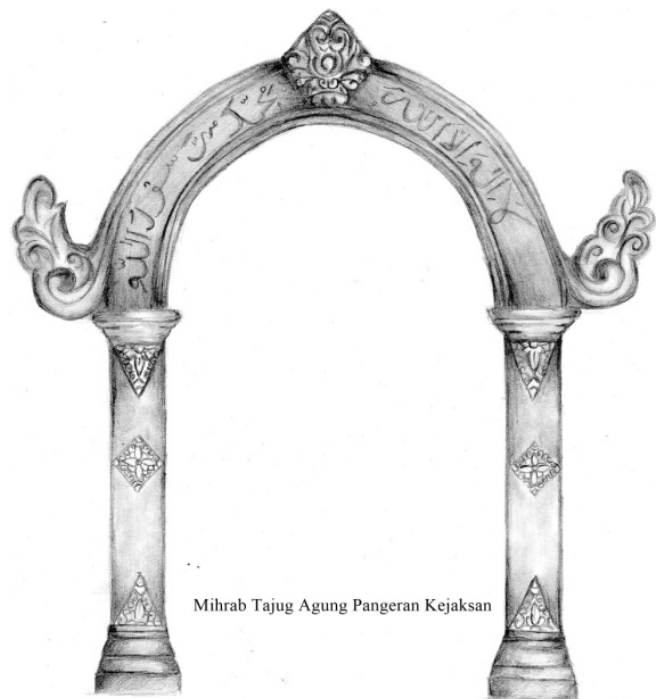

Image: Mihrab Illustration, (Nevita, 2018).

Tajug Agung Pangeran Kejaksan on the mihrab there is a cylinder with a quarter arch Arabic lafad "illallahu Laailaaha Muhammadarrosulullah" and lotus flowers blooming at the top of the arch. Roof arch-shaped mihrab arch and in the middle there is a floral motif. On the left and right poles mihrab ornate lotus blossom motif combined with leaves and tendrils. This motif is engraved on a rectangular field.

The next is the roof ornaments. Objects of art is the product of a culture that into the value system of a society, the meaning and aesthetics must be based on the concept of the people's culture. And, the concept of the mythical culture (Sumardjo, 2000) is essentially the original religion. By knowing the belief system, there is an interpretation system of all the results of culture, including the arts. Reason maintain the shape of the building Great Mosque of Cirebon, because the value of the history of the mosque. Great Mosque Sang Cipta Rasaas a monument to the struggle against colonialism in the Islamic society.

The roof shape Great Mosque of Cirebon, which has a rectangular roof. The number four has deep meaning associated with life; as disclosed (Kiai Azhari, July 24, 2016) related to the creation of Adam (the first prophet) made of four elements: earth, water, fire, wind; Humans were created: mani, madi, wadi, maningkem; Natural consisting of: nature spirits, natural content, nature of the Creed, the afterlife; Time consists of: morning, noon, afternoon, evening; Directions consisting of: west, east, north, south; Form consisting of: large, small, old, young. Of forms and meanings that consists of four numbers of the all-round, by local wisdom symbolized into a food kupat (rhombus) which means round four.

As expressed by Jakob Sumardjo (2014) regarding the aesthetic patterns of four contained in the maritime else as the cultivators, concerned with blood relationship than the relationship lokalitas. The Great Mosque Sang Cipta Rasa there are also images of the philosophy of numbers 3,6 and 9. Therefore, of the three figures were similar in each of the sum of the third lift. $3+3=6,3 \times 3=9$, and the sum of other inter-related to each other in the three figures. The third number is the number of philosophy used by the guardian (Wali Songo), because there is no other figure who resembles three figures. So in the entrance to Great Mosque Sang Cipta Rasadescribed from point 9 (Interview with Kiai Azhari, July 24, 2016).

The shape, size, and height of the building of the mosque also contains the numbers have meaning. As an example of 50 Islamic theology there shall God 20, Muhal God 20 shall Rasul 4, Muhal Rasul 4, and za'id and wanang The God of each one, and therefore the high 50. For aesthetic concept of the mosque, like a pillar amounted 
to 30,12 poles as the pillar, and 18 penggiring. 6 related to faith, 6 related to the family, and the rest of which 18 related to the community. Pole mosque outside numbers 44 , which is significantly related to the man who started life at the age 4x40 given day (Interview with Kiai Azhari, July 24, 2016).

The beauty of a building is a union of various factors such as function, construction and aesthetics. In other words Beauty is an order of parts manuals in their relations and in their relation to the whole. In duakategori, ie the constructional and komplemente (supporter) (Kusmiati, 2000).

In the study of meaning, a process symbolizing an aesthetic object is important because the meaning is sharply observed in the process of symbolization of a phenomenon or symbolization also initiated aesthetic. To that end, Langer role in the theories become more important. Symbol of "discursive" or that reason within the scope Neopositivisme, is a symbol of modern logic performing various analyzes disclosure. These symbols are clearly visible in the construction language logic. Each symbol represents one name, so that a row of symbols will be arranged according to certain syntactical rules produce an overview of a particular reality. Discursive symbol implies a structure built by the various elements that the data regularly to understand its meaning (Sachari, 2002).

There is a philosophy which is illustrated by the ocean, mountains and the sun, which also means Mungal, mangil and mungup. Mungal (with a picture of the sea) it means when entering the mosque between the heart and the mouth should be the same. Mangil the pictorial mountain, which means that if the job of the man was like a mountain, not cracked due to heat and does not escape because of the rain, there will be sun later inshaAllah (Mungup pictorial sun) can enlighten others. The concept is applicable both in terms of work, study or worship (Interview with Kiai Azhari, July 24, 2016). Great Mosque Sang Cipta Rasa Cirebon initially had a thatched roof, later renamed mesh (wood), and finally changed to tiles but the very top of the roof was replaced by a thatch back. The most substantial renovation in the Great Mosque Sang Cipta Rasa Cirebon occurred in 1978, and just change the mast and mast sections did not use nails, all of a pillar of the mosque using the number 6 in the pole sasak. Then meaning lotus flower, while the number 5 has the meaning pomegranate, The lotus flower is a meaningful sustainable, which is reflected on a worship that should continue to be continued, should not be broken. There is also a form of calligraphy in the mosque shaped pomegranate flowers. Calligraphy has a meaning of 'Dal' five, which refers to the letter of Al-Ikhlas (Interview with Kiai Azhari, July 24, 2016). while the number 5 has the meaning pomegranate. The lotus flower is a meaningful sustainable, which is reflected on a worship that should continue to be continued, should not be broken. There is also a form of calligraphy in the mosque shaped pomegranate flowers. Calligraphy has a meaning of 'Dal' five, which refers to the letter of Al-Ikhlas (Interview with Kiai Azhari, July 24, 2016). while the number 5 has the meaning pomegranate. The lotus flower is a meaningful sustainable, which is reflected on a worship that should continue to be continued, should not be broken. There is also a form of calligraphy in the mosque shaped pomegranate flowers. Calligraphy has a meaning of 'Dal' five, which refers to the letter of Al-Ikhlas (Interview with Kiai Azhari, July 24, 2016).

In general, detail artifacts mosque interior is old and quaint in Cirebon (built in the early development of Islam in Cirebon) to have similar characteristics, namely the size of the height of the wall under two meters and a small entrance so that the position of the pilgrims who will come to be slightly bent (Budi, 2015). The use of ceramics almost on every wall of an old building in Cirebon, not only in mosques saja. Uses ceramics found in old buildings in Cirebon is the influence of culture Tionghoa. There are abundant ceramics transferred its use to decorate the walls of an old building in Cirebon. In addition to the mosque, the tomb of Sunan Gunung Jati also seen the use of ceramics derived from Chinese and English. However, ceramics from England with the text contained in Malay language can be identified that the ceramics come from a later time. Assuming that emerged from the British ceramics affixed at a later time, after the cemetery buildings stand. The use of ceramics that serve as decoration became the hallmark characteristics of an old building in Cirebon (Chambert-Loir, 2011 and Yudoseputro, 1986).

Ceramic / porcelain in the mosque is one manifestation of which was considered the most representative works that express human civilization, and the object artifacts that prove the existence of an intention or desire to represents the something. The ceramic material itself has continuity with the entity elements of life such as water, earth, fire and air. By understanding the characteristics of the ceramic material is an aesthetic consideration which would also be supporting the prominent visual form (Wisesa, Taufik Flag; Teddy Moh. Darajat and Ismail Alif Siregar. 2017).

In addition, the use of ceramics is the influence of Chinese culture in Cirebon mosque before the founding of the palace is still strong influence of ceramic ornaments and structures typical Chinese architecture. In addition, the transfer functions of ceramics as an ornament also due to an abundance of ceramics in Cirebon then. Therefore, when Sunan Gunung Jati married Princess Ong Tin told of it brought four ships of more than 200 soldiers and ceramics as a gift. Ceramic gifts are then distributed to the public and also partly into ornaments are placed on the walls of the mosque. (Interview with RA Opan Safari Hashim, August 7th, 2017 and interviews with Elang Heryanto [Elang Ayi] and Rd. Elang Haafiz Permadi [Elang Nanang], March 17, 2017).

The use of motifs as decorative ornaments mosque bore the characteristics of an ancient mosque in the territory of the Sultanate of Cirebon.Bukan only for the mosque, but almost every ancient building in Cirebon 
using ornament. Like as ceramics as described in the preceding paragraph, in addition to the availability of abundant ceramics, the use of ceramics as a garnish were then grown into a typical motif in each building (including mosques) in the territory of the Sultanate of Cirebon. As described Husen Hendriyana, that motive is a journey, its own color in the arts and culture in Indonesia, with the peculiarities of each ornament each region. As such, an ancient motif found in carving gravestones and building temples, carvings that adorn the palace buildings, equipment or furniture.

Comparison Part roof, floor, and Fences

\begin{tabular}{|l|l|l|l|l|l|l|}
\hline \multirow{2}{*}{ name mosque } & \multicolumn{2}{c|}{ Roof } & \multicolumn{2}{c|}{ Floor } & \multicolumn{2}{c|}{ Fence } \\
\cline { 2 - 7 } & \multicolumn{1}{|c|}{ Form } & material & \multicolumn{1}{|c|}{ Form } & material & \multicolumn{1}{c|}{ Form } & \multicolumn{1}{c|}{ material } \\
\hline \hline mosque Pejlagrahan & ordinary & roof tile & $\begin{array}{l}\text { Coated, } \\
\text { not Land }\end{array}$ & Ceramic & ordinary & $\begin{array}{l}\text { Bricks and } \\
\text { Wood }\end{array}$ \\
\hline Merah Panjunan Mosque & joglo & Shingle & $\begin{array}{l}\text { Coated, } \\
\text { not Land }\end{array}$ & $\begin{array}{l}\text { Tehel and } \\
\text { Ceramics }\end{array}$ & Gate & Brick \\
\hline $\begin{array}{l}\text { Great Mosque of Cirebon } \\
\text { Kejaksan Supreme Prince }\end{array}$ & joglo & Shingle & $\begin{array}{l}\text { Coated, } \\
\text { not Land }\end{array}$ & $\begin{array}{l}\text { Tehel and } \\
\text { Ceramics }\end{array}$ & Gate & Brick \\
\hline
\end{tabular}

Among the four old mosque that was built in the early spread of Islam in Cirebon, Pejlagrahan mosque is a mosque that has experienced a change signifikan.Identifikasi initial architectural shapes and difficult to detect, while the related description form and early architecture Pejlagrahan mosque is based on the building of Merah Panjunan Mosque, Merah Panjunan Mosque regarded as a representation form and architecture of the mosque which was built in the early development of Islam in Cirebon (Budi, 2015). Over Mosque Pejlagrahan, changes in elevation, namely Pejlagrahan Mosque main prayer hall, porch additions pawestren in eastern and southern part Pejlagrahan Mosques. Some material mosque also underwent a change, namely meterial red tiles were originally replaced with white ceramic, ceramic coated walls of the prayer hall, and turn the cover material atap.Bale flower that was originally located on the back of the mosque, the mosque was moved to Perkambangan, then the main door of the mosque is now a door Pejlagrahan originating from the mosque Gamel. Of any changes taking place in the mosque Pejlagrahan, leaving some elements of pristine, such as wood columns, doors are small, wells, water pot for a purification ritual, ornaments ceramic plates on the walls and the pulpit. The original Momolo that was originally contained in the summit pyramid roof has been replaced, but the original momolo remain at the Pejlagrahan Mosque, but placed in the outer west side of the building just above the mihrab. Ceramic coated prayer room wall, and turn the cover material atap.Bale flower that was originally located on the back of the mosque, the mosque was moved to Pekambangan, then the main door of the mosque Pejlagrahan now a door from the mosque Gamel. Of any changes taking place in the mosque Pejlagrahan, leaving some elements of pristine, such as wood columns, doors are small, wells, water pot for a purification ritual, ornaments ceramic plates on the walls and the pulpit. The original Momolo that was originally contained in the summit pyramid roof has been replaced, but the original momolo remain at the Pejlagrahan Mosque, but placed in the outer west side of the building just above the mihrab (Budi, 2015). Ceramic coated prayer room wall, and turn the cover roof material. Bale flower that was originally located on the back of the mosque, the mosque was moved to Pekambangan, then the main door of the mosque Pejlagrahan now a door from the mosque Gamel. Of any changes taking place in the mosque Pejlagrahan, leaving some elements of pristine, such as wood columns, doors are small, wells, water pot for a purification ritual, ornaments ceramic plates on the walls and the pulpit. The original Momolo that was originally contained in the summit pyramid roof has been replaced, but the original momolo remain at the Pejlagrahan Mosque, but placed in the outer west side of the building just above the mihrab (Budi, 2015). moved to Masjid Pekambangan, then the main door of the mosque Pejlagrahan now a door from the mosque Gamel. Of any changes taking place in the mosque Pejlagrahan, leaving some elements of pristine, such as wood columns, doors are small, wells, water pot for a purification ritual, ornaments ceramic plates on the walls and the pulpit. The original Momolo that was originally contained in the summit pyramid roof has been replaced, but the original momolo remain at the Pejlagrahan Mosque, but placed in the outer west side of the building just above the mihrab.

Moved to Masjid Pekambangan, then the main door of the mosque Pejlagrahan now a door from the mosque Gamel. Of any changes taking place in the mosque Pejlagrahan, leaving some elements of pristine, such as wood columns, doors are small, wells, water pot for a purification ritual, ornaments ceramic plates on the walls and the pulpit. The original Momolo that was originally contained in the summit pyramid roof has been replaced, but the original momolo remain at the Pejlagrahan Mosque, but placed in the outer west side of the building just above the mihrab. The doors are small, wells, water pot for a purification ritual, ornaments ceramic plates on the walls and the pulpit. The original Momolo that was originally contained in the summit pyramid roof has been replaced, but the original momolo remain at the Pejlagrahan Mosque, but placed in the outer west side of the building just above the mihrab (Budi, 2015). the doors are small, wells, water pot for a purification ritual, ornaments ceramic plates on the walls and the pulpit. The original Momolo that was originally contained in the summit pyramid roof 
has been replaced, but the original momolo remain at the Pejlagrahan Mosque, but placed in the outer west side of the building just above the mihrab (Budi, 2015).

Given the changes in the shape and ornamentation Pejlagrahan Mosque has been very significant, but one fact that can not be sued is the existence of the mosque in the early Pejlagrahan near streams, hence the name 'Pejlagrahan' itself. In the world of architecture known as Culture Landscape (Landscape Culture) in the form of cultural spaces that are influenced by environmental conditions. For Cirebon, Landscape Budayannya limited by water (the sea). Based on information from texts and other data, construction of the mosque Pejlagrahan, too, was influenced by the Cultural Landscape Cirebon restricted (or may also be supported) by the sea (water) (Interview with RA Opan Safari Hashim, August $\left.7^{\text {th }}, 2017\right)$.

As mentioned previously, that the shape and architecture of Merah Panjunan Mosqueis a representation form and architecture of the mosque which was built in the early development of Islam in Cirebon, because the shape and architecture of Merah Panjunan Mosquefairly well-maintained. In 1978 the community around Merah Panjunan Mosquebuild a tower on the front page of the south, which then unload carved teak doors located on the front gate of the Merah Panjunan Mosque. However, the presence of the tower did not last long, which eventually dismantled again with consideration of architectural authenticity Panjunan Red Mosque. Another distinctive feature of each building old mosque in Cirebon is the absence of a tower at each mosque. Besides the tower is considered the influence of the Christian religion, where a fire tower.

The use of shingles as the main ingredient roof cover was dipertahankan.Juga, as a form of conservation efforts, the main prayer hall is only used twice in one year, when Eid al-Adha prayers and Eid prayers. As for prayer five times, using a space portico, with the entrance to the main prayer hall as the mihrab. In contrast to the mosque Pejlagrahan has changed significantly in form and architecture, but the authenticity of the ceramic on the wall as an ornament. Unlike the Merah Panjunan Mosque, ceramic ornaments originating from Chinese (Kwangtung) and comes from the colonial period, most of the original ceramic has been lost and replaced with ceramic plates Kasepuhan Palace collection donated to Merah Panjunan Mosque (Budi, 2015).

Tajug Agung Pengeran Kejaksan Mosque same as Pejlagrahan Mosque, the form and early architecture has changed significantly and shaped as mosques at the present time. However, ornaments ceramic plates contained in tajug wall can still be seen in tajug. Then the initial foundation Tajug Agung Pangeran Kejaksan still survive and can be seen in the pray room. Based on foundation made of wood, as well as the representation of the shape and architecture of the Merah Panjunan Mosque, assumptions about the shape and architecture of the Tajug Agung Pangeran Kejaksan early Tajug can be estimated. However, although it has undergone significant changes in the shape and architecture, wells and vases became ablution like that found in many ancient mosques in Cirebon can still be found on the north side tajug.

The use of motifs as decorative ornaments mosque bore the characteristics of an ancient mosque in the territory of the Sultanate of Cirebon. Not only for the mosque, but almost every ancient building in Cirebon using ornamnet. Like as ceramics as described in the preceding paragraph, in addition to the availability of abundant ceramics, the use of ceramics as a garnish were then grown into a typical motif in each building (including mosques) in the territory of the Sultanate of Cirebon.

Great Mosque Sang Cipta Rasa in the development of Islam in Cirebon had a special position among the top three mosques built in the early development of Islam in Cirebon. Great Mosque Sang Cipta Rasa development initiated by Sunan Gunung Jati, with Walisongo involvement in its development. Also, the influence of Sunan Gunung Jati who is also the leader for the people of Cirebon, strengthen the position of Great Mosque Sang Cipta RasaCirebon for society and communities under the current Cirebon Sultanate. As a result of that, the data and documents about the Great Mosque Sang Cipta Rasa was a little more than three mosques before. Begin of text to a note from the Dutch East Indies colonial government. Influence contained in the old mosque in Cirebon is of Chinese culture as well as Javanese and Sundanese culture. Pluralism in Cirebon itself also affect each building consisting of influence of each culture acculturated in Cirebon, which eventually form a unique and distinctive culture. 
Element Table Decoration On Mosque

\begin{tabular}{|l|c|c|c|c|c|c|c|c|}
\hline \multirow{2}{*}{ elements } & \multicolumn{2}{|c|}{ Mosque Pejlagrahan } & \multicolumn{2}{c|}{$\begin{array}{c}\text { Merah Panjunan } \\
\text { Mosque }\end{array}$} & \multicolumn{2}{c|}{$\begin{array}{c}\text { Tajug Supreme } \\
\text { Prince Kejaksan }\end{array}$} & \multicolumn{2}{c|}{$\begin{array}{c}\text { Great Mosque of } \\
\text { Cirebon }\end{array}$} \\
\cline { 2 - 9 } & There is & Not & There is & Not & There is & Not & There is & Not \\
\hline \hline Gate & & $-\bullet$ & $-\bullet$ & & $-\bullet$ & & $-\bullet$ & \\
\hline Momolo & $-\bullet$ & & $-\bullet$ & & $-\bullet$ & & & $-\bullet$ \\
\hline Porcelain & $-\bullet$ & & $-\bullet$ & & $-\bullet$ & & $-\bullet$ & \\
\hline Calligraphy & $-\bullet$ & & $-\bullet$ & & & $-\bullet$ & $-\bullet$ & \\
\hline Well & $-\bullet$ & & $-\bullet$ & & $-\bullet$ & & $-\bullet$ & \\
\hline Solarium & & $-\bullet$ & & $-\bullet$ & & $-\bullet$ & $-\bullet$ & \\
\hline Gallery & $-\bullet$ & & $-\bullet$ & & $-\bullet$ & & $-\bullet$ & \\
\hline Rostrum & $-\bullet$ & & $-\bullet$ & & $-\bullet$ & & $-\bullet$ & \\
\hline Mihrab & $-\bullet$ & & $-\bullet$ & & $-\bullet$ & & $-\bullet$ & \\
\hline Maskurah & & $-\bullet$ & & $-\bullet$ & & $-\bullet$ & $-\bullet$ & \\
\hline Inscription & & $-\bullet$ & & $-\bullet$ & & $-\bullet$ & $-\bullet$ & \\
\hline
\end{tabular}

The development of the mosque, in addition to affecting the surrounding community, can also be influenced by the people and conditions that developed aspects around masjid. Social aspect, cultural, economic and political also-in and influence the development of mosques, especially in terms of building and architecture. Especially the mosque, which is an important building in the Islamic religion and either directly or indirectly the presence of a mosque in tandem with the development of the Muslim community who were around the mosque (Budi, 2015: 28).

Every mosque has reached the age of more than a century, almost certainly significant changes have occurred either or not. With goal to continue to preserve and maintain it self. change happens mosque also vary, there is a total remodel, or renovate to maintain authenticity. Even renovating many times with the consequences of a total change of form and original architecture.

The political situation became one of the causes that drive change that characterizes the development of building moaque. Like as happened to Great Mosque Sang Cipta Rasa also feel the change of government policy (politics) the Dutch East Indies. As happened in the mid-1936-1937 Related alteration and renovation of the Great Mosque of Cirebon, recorded in the Antiquities Act of 1931 Moumenten Staadsblad Ordinance of the Department of Antiquities office in Semarang Krijgman leadership during the Dutch East Indies (see Chapter IV of things 174175 ). When Krijgman which gave the decision to restore the Great Mosque Sang Cipta Rasaas listed on the Antiquities Act Staadsblad 1931Monumenten Ordinance of the Department of Antiquities office in Hyderabad under leadership Krijgman (Sudjana, 2003: 17).

However, the changes that occur in response to environmental conditions can also be a cause for doing change. As happened with the Great Mosque Tajug Pejlagrahan and Prince Kejaksan, which exalts the main Pray room. Coused by soil conditions (environment) around which does not allow (Budi , 2015). Development building a mosque, as well as the surrounding community cultural development, as well as the development of other aspects of life; social, economic and political, which coexist.

Which contained about iconografer committed mem "read" the image as text and art historians treat it as an artifact, needed an innovative observation to criticize the picture. In his study of the ancient mosque located in the vicinity of the Sultanate of Cirebon, iconografer related analysis can be done on elements of decoration of mosques are porcelain or pictorial plates were found in all the ancient mosque in Cirebon as the influence of Chinese culture on the surrounding community. On the porcelain decoration element variations of different images, from images of plants, animals up calligraphy that can be interpreted the meaning deeper through iconografer. Besides iconografer in Lynn Hunt in his book also discusses the use of symbols by the authorities, artistic styles and modes of image and ideology that represents the message to be conveyed. In ancient mosque in Cirebon symbols with different meanings can be seen through the ornate carving or engraving an image in the form of the sun, the lotus flower and vine-tendrils. All motifs is found almost all the trimmings mihrab and mimbar mosque, partly found in the engraving window and pole.

When entering an area of an ancient mosque located in the Sultanate of Cirebon it will be seen that thick acculturation between local elements and the influence of outside elements such as Chinese and Arabic. The elements of decoration found on an ancient mosque in the meaning will then bring a view of an interpretation of the audience (in this case the visitor mosque) which is triggered by the presence of elements of the ornament itself. When looking at the calligraphy in several ancient mosques around the Sultanate of Cirebon, it will show the influence of the Arab element that mixes with the local elements (parts of other buildings). Likewise when viewed porcelain used as wall hangings in various corners of the building of the mosque, the Chinese influence is very dear to them, it makes the visitor has his own interpretation of the symbols of the image contained in the porcelain decoration elements. In other words, what is understood not to be separated from what is presented to the senses 
as seen by the audience. Lynn Hunt describes this phenomenon as the "Framing". "Framing" is found in many Renaissance paintings, the effect of "framing" are they "invite" the audience to see the world in a frame (window). The mosque is like a "framing" which then will take visitors on a variety of interpretations through parts building and decoration contained therein. Lynn Hunt describes this phenomenon as the "Framing". "Framing" is found in many Renaissance paintings, the effect of "framing" are they "invite" the audience to see the world in a frame (window). The mosque is like a "framing" which then will take visitors on a variety of interpretations through parts building and decoration contained therein. Lynn Hunt describes this phenomenon as the "Framing". "Framing" is found in many Renaissance paintings, the effect of "framing" are they "invite" the audience to see the world in a frame (window). The mosque is like a "framing" which then will take visitors on a variety of interpretations through parts building and decoration contained therein.

Lynn Hunt also pointed out the study of meaning in paintings in the ceilling, camera Degli Sposi, when looking into the ceilling there is a contrast between the "world" above and below it. The world below illustrates the public zone, clearly dominated by male activities, while the "world above further describe the pleasure, inspiration, feminine exotic, and it contained the blueprint antik.Selain mendudukan how the painter put his paintings of space and audiens. In mosque, meaning related to the world above, and below the interpreted in several patterns that are actualized through the interior and exterior of the mosque, even it can simply be seen from the roof of the mosque was meant as a world self. Part that houses the world over the middle and under. A part interior of the building is defined as the center human activity, meanwhile,

\section{Conclusion}

The problems that have been described so far author uses anthropological approach is also used to view the design objects as artifacts from the close through human visionaries. By highlighting the human aspects of a design object or objects and human relations. Ethnography is one of the classical methods in antropologi. Etnografi (Walker, 2010) aims to understand the meaning of community, which is of course different meaning in the context of semiotics or hermeneutics. By using ethnographic methods, the complexity of the people residing around four mosques that became the object of research the author can see. Relationship affect the influence of Mosques society or vice versa, between communities and mosques, can be seen and then analyzed.

Reinforced with the approach of social history, which is a new phenomenon in the writing of history since before World War II. Attention social history includes a lot of things related to aspects of society. Kuntowijoyo, a historian who has an attention to social history, explained that the themes of social history such as the social classes, social events and social facts, as if the institutionalized into a specialization by isolating the theme of arable, of a very complex problem. Kuntowijoyo, citing EJ Hobsbawm, trying to legitimize the so-called "societal history" or history of society "to distinguish the social history of writing about things that are described above (Kuntowijoyo, 1994). In contrast to the ethnography, social history focusing on the time of the space in a penelitian.Oleh because the study authors, about the visual development of the mosques in the Sultanate of Cirebon views of social change always change over time. On the other hand, the mosque still preserves its authenticity. It was an object of the uniqueness of its own research into wealth.

In studying the problems Meaning of visual elements in the Sultanate of Cirebon mosque, among others:

1. Their visual changes or developments in the Sultanate of Cirebon mosque, because of the influence of social history (the people) are still firmly on the rules and policies issued by the Sultan as a traditional ruler in the Sultanate of Cirebon.

2. The factors or variables that cause changes of the visual elements on a mosque in Cirebon Sultanate regions are correlated with conditions of political, social, cultural, and economic Cirebon.

3. Meaning of the visual elements of the mosque as a result of mixed culture between religious cultures and beliefs. Religious culture and beliefs closely associated with the symbol of cultural artifacts in this mosque. Besides showing their meaning and aesthetic value on the visual elements.

4. The mosque as a meeting place eliminating social classes in society. However, activity in it is inseparable from the interests masyarakat.Hal it also shows the influence of culture on social interaction in the spirit of his time (zeitgeist).

In some areas of Indonesia still has tradisionaldan kingdoms have such power over their traditional territory. Model mosque be one measure of the presence of the royal palace on tradisionaltersebut. The study was expected to enrich the local history in Indonesia, particularly the city of Cirebon, West Java. In Beyond that, other benefits are also expected from this study is the occurrence of synergy or mutual reinforcement approach (reapproachment) between the history of art and design. Assessment of art and design that is experiencing dynamic development, with this study, is expected to strengthen the historical perspective.

\section{References}

Atja. Carita 1986. Purwaka Caruban Nagari; Literature as a Source History knowledge, Bandung: Development Project of Museum West Java. 
Bakker SJ, JWM (1984): An Introduction to the Philosophy of Culture, Jakarta, BPK Gunung Mulia, 136.

Poestaka hall. 1926. The Tomb Doenia Masdjid and Islam. Weltevreden: Balai Poestaka.

Cassirer, Ernst. (1987): Man and Culture: An Essay On Man. Jakarta, Gramedia,

Chambert-Loir, Henry and Claude Guillot. (2007): Pilgrimage and Trust in the Islamic World. Jakarta: Serambi.Hal.333-361.

Dienaputra, Reiza D. (2011). Transformation Visual Coat Political Parties In Indonesia from 1955 to 2004.Dissertation of the ITB. Bandung: ITB.

Dienaputra, Reiza D. (2015): Breaking Visual History, Bandung, Balatin Primary, 44, 60.

Ekadjati, Edi S., et al. (1991). Independence Revolution History of West Java. Bandung: Ministry of Education and the Directorate of History and Traditional Values Local Culture.

Endraswara, Suwardi. 2006. Culture Research Methodology. Yogyakarta: Gadjah Mada University Press.

Islamic Encyclopedia Volume 3 KAL-NAH, 1994. Jakarta: New Ichtiar van Hoeve.

Gottschalk, Louis. (1986): Understanding History, UI Press, 32.

Haldani D., Achmad. (2013): Authenticity Style Decorations Great Mosque City Districts; A shift Assessing Aesthetic Value, Dissertation Institute Technology Bandung, FSRD.

Hendriyana, Husen. (2016): Meaning of Aesthetic and Symbolic Motifs Liman and Pomegranates in Sadguna concept in Cirebon Keraton Period Kasepuhan I (1678-1698) - Kasepuhan II (1698-1723), Dissertation, Institute Technology Bandung, FSRD.

Irianto, Bambang. (2012): Bendera Cirebon (Banners Caruban Nagari) AjaranKesempurnaan Life, Jakarta: Textile Museum

Irianto, Bambang and Ki Tarka Sutarahardja. 2013. History of Cirebon; script Keraton Kacirebonan, Yogyakarta: Deepublish.

Irianto, Bambang and Ki Tarka Sutarahardja (rather character and language). 2013. Babad Cirebon; Kandha Carub Tangkil manuscript. Yogyakarta: Deepublish.

Kleinsteuber, Asti and Syafri M. Maharadjo. Ancient mosques 2012. In Indonesia; Heritage From Time To Time, Jakarta: PT. US Productions Indonesia.

Pijper, GF1984. Several studies of the history of Islam in Indonesia from 1900 to 1950.Jakarta: UI Press. 1992. Four studies on Islam in Indonesia from 1930 to 1950. Jakarta: UI Press.

Prawiraredja, Mohammed Lewis. (2005): Cirebon, philosophy, tradition, and Indigenous Culture, Jakarta: Indonesian Government Printing Perum. 11-13

Raffles, Thomas Stamford. (2014): The history of Java (trans.). Jakarta: Narrative. 170.

Ratna, Nyoman Kutha. (2008): Theory, Methods and Techniques Research Letters. Yogyakarta: Student Library.

Rodrigues, Francisco. (2014): Suma Oriental, journey from the Red Sea to ethnic Chinese (Trans.). Yogyakarta; Ombak.255-256.

Rohidi, Tjetjep Rohendi. (2011): Research Methodology. Semarang: Prima Cipta Archipelago.

Suganda, Dada et al. 2011.Visualization remains of Islamic history in Tatar Sunda 1600-1942 (Edition Priangan). Jatinangor: Literature Padjadjaran University Press.

Sulendraningrat, 1985. Sejarah Cirebon. Jakarta: PN Balai Pustaka

Sulendraningrat, PS. Tth. Babad Tanah Sunda; Babad Cirebon. Cirebon: TNP. Publisher.

Sumardjo, RH Unang. 1983. Reviewing Stage glance History Cerbon Kingdom Government 1479-1809, Bandung: Tarsito.

Suraatmadja, R. 1917. Boekoe Tjarita Babad Cirebon. Batavia: Kho Tjeng Bie.

Team Foundation Partners Indonesian culture. 1982. Cerbon. Jakarta: Sinar Harapan.

Tjandrasasmita, Uka. 2009. Islamic Archeology Archipelago. Jakarta: KPG.

Wahju, Amman N. (2005): History of Syarif Hidayatullah Shaikh Wali Sunan Gunung Jati (The script Mertasinga). Bandung: Pustaka. Case 151.

Wardiya, Amin. (2006): Sunan Gunung Jati Not Falatehan. Cirebon: Agency Communication Culture and Tourism of Cirebon.

Magazine, articles, newspapers, etc.

Parahiangan Number. 10, 5 Maart 1936 Year VIII. "Masjid Agung Tjirebon ". It 153-154.

Volksalmanak Soenda (Sundanese) year (1922): "Excerpts Tina Chronicle Tjirebon "on page 182-186.

\section{Internet}

https://www.google.co.id/maps/place/Masjid+Agung+Sang+Cipta+Rasa+Kasepuhan, accessed on 2 June 2017, at $17.34 \mathrm{WIB}$

https://www.google.co.id/maps/place/masjid+PEJLAGRAHAN/,accessed 2 June 2017, 18.43 WIB.

https://www.google.co.id/maps/place/Masjid+Merah+Panjunan, accessed on 2 June 2017, at 20.32 WIB.

https://www.google.co.id/maps/place/Tajug+Agung+Pangeran+Kejaksan+Cirebon, accessed on 2 June 2017, 


\subsection{WIB.}

\section{First A. Author}

1 Nyai Kartika, was bornin Bogor (West Java), 02/01/1976. Currently studying Doctoral at Faculty of Art and Design, Bandung Institute of Technology. Completed Bachelor degreefrom Department of History, Faculty of Humanities,Universitas Padjadjaran, and master degree at the same concentration at Faculty of Cultural Studies, UniversitasIndonesia. Several books written: Sejarah Ciamis (Tim).Sejarah Majalengka;Sindangkasih-MadjaMadjalengka (Mandiri);Visualisasi TinggalanSejarah Islam Di Tatar Sunda 1600-1942 (Edisi Priangan) (Tim);

\section{Second A. Author}

2 Yasraf Amir Piliang, was born in Maninjau (West Sumatera), 09/30/1956. From 1996 until now is a teacher assistantof graduate school of Faculty of Art and DesignBandung Institute of Technology. Actively writes in various mass media and journals. Writes books, some of which: Dunia yang Dilipat: Tamasya Melampaui BatasBatas Kebudayaan, Penerbit Jalasutra, 2004; Pos-realitas: Realitas Kebudayaan di dalam Era Pos-metafisika, Penerbit Jalasutra, 2004; Transpolitika: Dinamika Politik dalam Era Virtualitas, Penerbit Jalasutra, 2006; Multiplisitas dan Diferensi, Penerbit Jalasutra, 2007; Semiotika dan Hipersemiotika, Penerbit Matahari, 2012; Agama dan Imajinasi: Mencari Tuhan-tuhan Digital, Penerbit Mizan, 2011

\section{Third A. Author}

3 Imam Santosa, currentlyofficiatedas the dean of Faculty of Art and Design, Bandung Institute of Technology. CompletedBacheloruntilDoctoral degreeat Faculty of Art and Design, Bandung Institute of Technology. Some of his worksarePerencanaan Pengembangan Interior Renovasi Gedung Merdeka Bandung (2003). Perencanaan Arsitektur dan Interior Bank DKI-Syariah Cabang Tanah Abang Jakarta; Bank Cabang Tanjung Priuk Jakarta (2003). Perencanaan Arsitektur dan Interior Museum Gunung Api Merapi, Yogyakarta (2004). Perancangan Interior Sentosa International Hospital, Bandung (2004).

\section{Fourth A. Author}

4 Reiza D. Dienaputra is a lecturer in the History of the Faculty of Cultural Sciences, Padjadjaran University. An undergraduate degree was obtained from Padjadjaran University (1987), a Masters degree from Gadjah Mada University (1997), and a Doctorate from the Bandung Institute of Technology's Postgraduate School (2011). Since he was in college (1986), he actively wrote various articles in a number of mass media, both national and regional. His articles were published, among others, in the daily Pikiran Rakyat, Galamedia, People's Sovereignty, Republika, Merdeka, Media Indonesia, and Kompas. He is also a guest speaker for several local and national TV stations, including Bandung TV, TVRI Jabar-Banten, CT Channel, IM TV and Metro TV. The works he has made include: The Military World in Indonesia: The Existence and Role of the Military in Sulawesi (Gadjah Mada University Press, 2000, joint work); History of the Tatar Sunda (Padjadjran University Research Institute, 2003, joint work); Cianjur: Between Priangan and Buitenzorg (Prolitera, 2004, individual works); Kota Lama Kota Baru: History of Indonesian Cities (Publisher Waves-NIOD-Airlangga University, 2005, joint work); Sundanese: History, Culture, and Politics (Literature Unpad Press, 2011, individual works); Oral History: Methods and Practices (Balatin Pratama, 2013, individual works) and Hacking Visual History (Balatin Pratama, 2015, individual works). 